NOTES FROM THE U. S. BUREAU OF CHEMISTRY.*

STUDIES IN NUTRITION. VIII. THE NUTRITIVE VALUE OF THE PROTEINS OF TOMATO-SEED PRESS CAKE. ${ }^{1}$

\author{
By A. J. Finks and Carl O. Johns.
}

[ABSTRACT.]

A DIET in which tomato-seed press cake furnished the sole source of protein and water-soluble vitamine enabled albino rats to grow at the normal rate. Such a diet was made adequate by the addition of starch, a suitable inorganic salt mixture, butter-fat, and lard. Normal growth was also obtained when the butter-fat of the above diet was replaced by lard.

\title{
THE APPLICATION OF OPTICAL METHODS TO THE EXAMINATION OF INSECTICIDES AND FUNGICIDES."
}

By George L. Keeman.

[ABSTRACT.]

Attentron has been called to the application of optical-crystallographic methods for the identification of crystallizable chemical salts in insecticides and fungicides. The Bureau has found the use of such methods of value in many instances. A single method of procedure, particularly suitable for microanalysts who have not had extensive training in crystallography and mineralogy, has been outlined.

* Communicated by the Acting Chief of the Bureau.

${ }^{1}$ Published in Am. J. Physiol., 56 (1921), 404.

"Published in J. Am. Pharm. Asso., 10 (192I), 336. 